\title{
Antiproliferative activity of hexane extract from Tunisian Cistus libanotis, Cistus monspeliensis and Cistus villosus
}

\author{
Mariem Ben Jemia', Mohamed Elyes Kchouk', Felice Senatore², Giuseppina Autore ${ }^{3}$, Stefania Marzocco ${ }^{3}$, \\ Vincenzo De Feo ${ }^{3 *}$ and Maurizio Bruno ${ }^{4}$
}

\begin{abstract}
Background: As a part of our investigation on Tunisian medicinal plants, we have carried out a phytochemical investigation of the hexane extracts from leaves of Cistus libanotis, C. villosus and C. monspeliensis, evualuating also their possible antiproliferative activity in vitro.

Results: The major compounds of hexane extracts were identified and quantified by GC-MS. The composition of the three species, although belonging to the same genus, is completely different. The antiproliferative activity was evaluated against murine monocyte/macrophages (J774.A1), human melanoma cells (A-375), and human breast cancer cells (MCF-7), showing major activity against the human melanoma cell line A-375.

Conclusions: The chemical composition of the hexane extracts from the three Cistus species can be useful in the chemosystematics of this complex genus. The preliminary antiproliferative activity against human melanoma cell line A-375 deserve further investigations in order to determine the compounds, or their combinations, which are the main responsible for the antiproliferative activity and its possible mechanism(s) of action.
\end{abstract}

\section{Background}

Cistaceae is a Mediterranean native family of almost 200 species of shrubs. Most members of this family are very fragrant and sweet smelling, being much appreciated in the perfume industry and for ornamental purposes. Also, Cistaceae plants adapt easily to wildfires that destroy large forest areas, their seeds resisting and repopulating rapidly in the following season [1]. This family is formed by different genera, including Helianthemum, Halimium and Cistus. This latter contains between 16 and 28 different species, depending on the source [2]. Some of the Cistus species are endemic and others are widespread in the Iberian Peninsula, Canary Islands, Northwestern Africa, Italy, Greece and Turkey [3]. The species are disseminated over different areas of the Mediterranean area, but not all the species are distributed following the same pattern. Thereby, each area is colonised by

\footnotetext{
* Correspondence: defeo@unisa.it

${ }^{3}$ Department of Pharmacy, University of Salerno, via Ponte Don Melillo, 84084, Fisciano (Salerno), Italy

Full list of author information is available at the end of the article
}

different Cistus species depending on climatological and soil conditions.

Traditional folk medicine has used Cistus species as antiinflammatory, antiulcerogenic, wound healing, antimicrobial, cytotoxic and vasodilator remedies. Recent studies highlighted some information on the possible candidate compounds for these effects, and new activities are being discovered and attributed to Cistus extracts. These include antimicrobial, antioxidant, antiproliferative, antinociceptive and analgesic effects [4-6].

A comprehensive study on the qualitative composition of the hexane extract of $C$. monspeliensis $\mathrm{L}$. leaves has been reported [7] as well as the catechin related compounds in aqueous extracts of the same species [8]. The composition of aqueous extracts from Cistus libanotis L. has also been reported [9]. No previous reports on the composition of $C$. villosus $\mathrm{L}$. are available.

Here we present a comparative qualitative and quantitative study of the composition of hexane extracts from the aerial parts of three Cistus species grown in Tunisia. Hexane extracts from Cistus monspeliensis, C. libanotis
(C) Chemistry Central

C 2013 Ben Jemia et al.; licensee Chemistry Central Ltd. This is an Open Access article distributed under the terms of the Creative Commons Attribution License (http://creativecommons.org/licenses/by/2.0), which permits unrestricted use, distribution, and reproduction in any medium, provided the original work is properly cited. 
Table 1 Percentage composition of the hexane extract from aerial parts of three Cistus spp

\begin{tabular}{|c|c|c|c|c|}
\hline Component & $\mathrm{K}_{\mathrm{i}}$ & $\% \mathrm{CL}$ & $\% \mathrm{CM}$ & $\% \mathrm{CV}$ \\
\hline Hydrocarbons & & 9.3 & 22.8 & 37.3 \\
\hline Tricosane & 2300 & & $\mathrm{t}$ & 0.1 \\
\hline Pentacosane & 2500 & 2.4 & 1.8 & 3.1 \\
\hline Heptacosane & 2700 & 2.2 & 6.1 & 6.6 \\
\hline Octacosane & 2800 & 0.3 & 3.6 & $\mathrm{t}$ \\
\hline Nonacosane & 2900 & 3.3 & 7.1 & 18.3 \\
\hline Hentriacontane & 3100 & 1.1 & 4.2 & 9.2 \\
\hline Carbonylic compounds & & & 0.7 & 2.2 \\
\hline Undecan-2-one & 1287 & & 0.7 & 2.2 \\
\hline Monoterpene hydrocarbons & & 10.5 & 2.1 & 0.9 \\
\hline Tricyclene & 928 & 0.1 & & \\
\hline a-Thujene & 931 & 0.1 & & \\
\hline a-Pinene & 938 & 2.1 & & \\
\hline Camphene & 953 & 3.6 & & \\
\hline Sabinene & 973 & 1.2 & & \\
\hline$\beta$-Pinene & 980 & 3.0 & & \\
\hline a-Terpinene & 1012 & 0.3 & & \\
\hline p-Cymene & 1025 & 0.1 & 0.8 & 0.3 \\
\hline Limonene & 1030 & & 1.3 & 0.6 \\
\hline Sesquiterpene hydrocarbons & & 1.5 & $\mathrm{t}$ & \\
\hline Cyclosativene & 1363 & $\mathrm{t}$ & & \\
\hline a-Copaene & 1377 & $\mathrm{t}$ & & \\
\hline a-Elemene & 1398 & 0.2 & & \\
\hline$\beta$-Caryophyllene & 1414 & 0.7 & & \\
\hline Widdrene & 1433 & & $\mathrm{t}$ & \\
\hline y-Elemene & 1438 & $\mathrm{t}$ & & \\
\hline a-Humulene & 1455 & 0.1 & & \\
\hline allo-Aromadendrene & 1463 & 0.4 & & \\
\hline 1-S-cis-Calamenene & 1520 & 0.1 & & \\
\hline Oxygenated monoterpenes & & 6.6 & 2.0 & 1.1 \\
\hline 1,8-Cineole & 1034 & 0.1 & 1.1 & 0.4 \\
\hline cis-Sabinene hydrate & 1063 & $\mathrm{t}$ & & \\
\hline trans-Sabinene hydrate & 1086 & 0.7 & & \\
\hline a-Campholenal & 1128 & $\mathrm{t}$ & & \\
\hline Camphor & 1145 & 0.7 & & \\
\hline Borneol & 1167 & 1.2 & & \\
\hline Myrtenol & 1197 & 0.3 & & \\
\hline Linalyl acetate & 1277 & 0.7 & 0.9 & 0.7 \\
\hline Isobornyl acetate & 1284 & 0.3 & & \\
\hline Bornylacetate & 1286 & 1.8 & & \\
\hline a-Terpenyl acetate & 1343 & 0.8 & & \\
\hline Oxygenated sesquiterpenes & & 0.7 & 1.4 & 1.2 \\
\hline Globulol & 1587 & $\mathrm{t}$ & & \\
\hline Viridiflorol & 1593 & 0.4 & 1.4 & 1.2 \\
\hline
\end{tabular}


Table 1 Percentage composition of the hexane extract from aerial parts of three Cistus spp (Continued)

Caryophylla-4(12),8(13)-dien-5 $\beta$-ol;
Caryophylla-3,8(13)-dien-5- $\beta$-ol
Diterpenes
Neophytadiene
Cembrene
Manoyloxide
13-epi-Manoyl oxide
(E)-Phytol
2-keto-manoyl oxide
3 3 -hydroxy- 13-epi- manoyl oxide

Fatty acids and derivatives

Cinnamic acid

Dodecanoic acid

Tetradecanoic acid

Pentadecanoic acid

Phthalic acid, diisobutyl ester

$(Z, Z, Z)-9,12-15-O c t a d e c a t r i e n o i c ~ a c i d$

$(Z, Z)-9,12-$ Octadecadienoic acid

Octadecanoic acid

Eicosanoic acid

Docosanoic acid

Tricosanoic acid

Tetracosanoic acid

Pentacosanoic acid

Hexacosanoic acid

Heptacosanoic acid

\section{Phenolic compounds}

Carvacrol

2,5-di-tert-butylphenol

$\mathrm{BHT}$

\section{Flavonoids}

Apigenin dimethyl ether (Genkwanin 4'-methyl ether)

Quercetagetin 3',4',6,7-tetramethyl ether

Quercetin 3,7,3',4'-tetramethyl ether (Retusin)

\section{Others}

Dihydroctinidiolide

Vitamin E

$\gamma$-Sitosterol

$\beta$-Amyrine

a-Amyrine

3ß-Acetyloxyolean-12-en-28-oic acid methyl ester (Oleanolic acid methyl ester acetate)

Total amount of compounds

$\begin{array}{ll}1640 & 0.2 \\ 1649 & 0.1 \\ & \mathbf{2 . 2}\end{array}$

2.2

3.8

4.8

1838

2.2

1.2

t

2.5

1989

1994

2132

2210

2273

24.4

1397

1566

1768

1863

1871

2099

2122

2172

2327

2526

2628

2730

2829

2934

3032

1299

1513

1515

$\mathbf{R}_{\mathrm{t}}$

30.2

0

43.26

43.36

5.6

24.6

0.1

47.18

19.26

3.3

16.2

32.8

47.65

3.3

0.2

0.7

51.50

52.14

53.16

65.18

$\mathrm{K}_{\mathrm{i}}$ : linear retention indices; $\mathrm{R}_{\mathrm{t}}$ : retention times; t: traces, less than 0.05\%; CL: Cistus libanotis; CM: Cistus monspeliensis; CV: Cistus villosus. 
and C. villosus leaves were analyzed by GC-MS. Moreover, the antiproliferative activity against a panel of cancer cell lines has been evaluated.

\section{Results and discussion}

\section{Chemical composition of hexane extracts}

As a part of our investigation on Tunisian medicinal plants, we have conducted a phytochemical investigation of the hexane extracts of Cistus libanotis, Cistus villosus and Cistus monspeliensis, evaluating also their possible antiproliferative activity against murine monocyte/macrophages (J774.A1), human melanoma cells (A-375), and human breast cancer cells (MCF-7). The composition of the three hexane extracts was achieved by GC-MS. Although the three species belong to the same genus, the composition of their hexane extract is completely different (Table 1). A total of 47 constituents, representing $90.1 \%$ of the total extract, have been identified from the hexane extract from the leaves of C. libanotis. In Table 1 , the retention indices, retention times and percentage composition are given; the components, grouped in class of substances, are listed in order of elution on a HP $5 \mathrm{MS}$ column. By far flavonoids (30.2\%) were the main fraction of the extract, with quercetagetin $3^{\prime}, 4^{\prime}, 6,7-$ tetramethyl ether $(24.6 \%)$ as the principal compound. The main component of fatty acids fraction (24.4\%) was (Z,Z,Z)-9,12-15-octadecatrienoic acid (23.5\%). Monoterpene hydrocarbons were also present in good amount (10.5\%), being camphene $(3.6 \%)$ and $\beta$-pinene $(3.0 \%)$ the principal compounds. Hydrocarbons and oxygenated monoterpenes represented $9.3 \%$ and $7.1 \%$, respectively. Diterpenes (2.2\%), sesquiterpenes (1.3\%) and oxygenated sesquiterpenes $(0.7 \%)$ were present in small amount. In C. monspeliensis (36 compounds) extract the principal class was represented by fatty acids (43.3\%) among which the most abundant were $(Z, Z, Z)-9,12-15$-octadecatrienoic acid (14.7\%) and (Z,Z)-9,12-octadecadienoic acid (6.6\%). Hydrocarbons (22.8\%) are also present in good amount with nonacosane $(7.1 \%)$ and heptacosane $(6.1 \%)$ as principal ones. Vitamin E was present (11.5\%) in higher amount with respect to C. libanotis (3.3\%). Monoterpenes, oxygenated monoterpenes, diterpenes and triterpenes were present in quite low amount. The peculiar characteristic of the composition of the extract of C. villosus is the high quantity of hydrocarbons (37.3\%), being nonacosane (18.3\%) and hentriacontane (9.2\%) the main compounds. Fatty acids (10.6\%) and diterpenes (4.8\%) were also present in good amount. It is noteworthy the good quantity of vitamin $\mathrm{E}(22.7 \%)$, the most abundant products among the 31 compounds of the extract of $C$. villosus.

Few reports are available in literature about the chemical constituents of Cistus species. The analysis of the composition of a hexane extract of leaves of C. monspeliensis collected in the island of Crete [7] indicated the presence of 13-epi-manoyl oxide, completely absent in our sample, which contains on the contrary a good quantity of manoyloxide. The available literature reports also chemical studies on the composition of extracts of Cistus species, obtained by different solvents. Catechin related compounds were also identified in the aqueous extracts of Cistus monspeliensis [8]. Some studies have reported the existence of monomeric and polymeric flavanols, gallic acid, rutin and diterpenes in several parts of Cistus incanus [10-12]. Previous studies have shown the presence of oligomeric proanthocyanidins in Cistus albidus [13]. Polyphenols in water extracts of C. libanotis and C. monspeliensis collected in Spain, have also been reported [9]. The concentration and the presence of different compounds in plants are not only species specific but they also depend on soil fertility and $\mathrm{pH}$, light intensity, plant age or temperature stress [14].

The presence of flavonoids in Cistus has been well documented. In fact, previous reports showed the occurrence of apigenin, quercetin and kaempferol derivatives in exudates of C. ladanifer leaves and in soil where these plants grew $[15,16]$, and this has been related to its allelopathic potential. In the extract of $C$. libanotis we detected as main compounds quercetin 3,7,3',4'-tetramethyl ether (retusin) (24.6\%) and 5.6\% of apigenin dimethyl ether (genkwanin 4'-methyl ether).

\section{Cytotoxic activity of the extracts}

The cytotoxic activity of three Cistus extracts against three cancer cell lines, including murine monocyte/macrophages, J774.A1, human melanoma cells, A-375, and human breast cancer cells MCF7, was determined, through the MTT conversion assay [17]. In Table 2 we showed the $\mathrm{IC}_{50}$ values, that represent the concentration expressed as $\mathrm{mg}$ of dry extract $/ \mathrm{ml}$ of the different hexane extracts of C. libanotis, C. villosus and C. monspeliensis

\begin{tabular}{|c|c|c|c|}
\hline \multicolumn{4}{|c|}{$I C_{50} 72 \mathrm{~h}$} \\
\hline Compound & J774A.1 & MCF7 & A375 \\
\hline Cistus libanotis & N.D. & N.D. & N.D. \\
\hline Cistus monspeliensis & N.D. & N.D. & $52.44 \pm 3.69$ \\
\hline Cistus villosus & N.D. & N.D. & N.D. \\
\hline 6-mercaptopurine & 0,003 & 48,23 & 142,36 \\
\hline
\end{tabular}

$\mathrm{IC}_{50}$ values for different cancer cell lines are expressed in $\mathrm{mg} / \mathrm{mL}$ for extracts and in $\mu \mathrm{M}$ for $6-\mathrm{MP}$, used as reference drug. The $I C_{50}$ value is the concentration of compound that affords $50 \%$ reduction in cell growth after 3 days incubation. Values are expressed as mean $\pm S D, n=3$. 
that affords a $50 \%$ reduction in cell growth after $72 \mathrm{~h}$ incubation time. Both extracts obtained from C. libanotis and $C$. villosus were inactive against all tested cell lines. The $50 \%$ cytotoxic concentration $\left(\mathrm{IC}_{50}\right)$ could not be estimated. A pronounced growth inhibition was showed by $C$. monspeliensis hexane extract against A-375 cell line, with a $\mathrm{IC}_{50}$ value of $82.42 \pm 2.92 \mathrm{mg} / \mathrm{ml}$ at $24 \mathrm{~h}$ and $52.44 \pm 3.69 \mathrm{mg} / \mathrm{ml}$ at $72 \mathrm{~h}$. Our results indicated higher activity of $C$. monspeliensis extract if compared to 6mercaptopurine (means $\mathrm{IC}_{50}=142,36 \mathrm{mg} / \mathrm{ml}$ at $72 \mathrm{~h}$ ) used as reference drug (Table 2).

Natural extracts have been previously reported as a potential source of antiproliferative compounds [18-20]. In this sense, it is accepted that the chemopreventive and tumor-inhibitory effect associated to some dietary antioxidant polyphenols could be due to their capability to inhibit oxygen reactive species (ROS) or free radicals [21]. More recently, a large body of studies is evidencing the ability of these compounds to modulate uncontrolled proliferation pathways or protooncogen expression [22]. Therefore, it is certainly plausible that the antiproliferative activity against A-375 cell line of the hexane extract of Cistus monspeliensis compounds could be related to their radical scavenging activity too.

Phenolic compounds have been traditionally associated to biological activities such as antioxidant, antimicrobial or cytotoxic. A recent study on the anticancer activity of several tea extracts with high polyphenolic content has reported $\mathrm{IC}_{50}$ values within the range $0.1-0.5 \mathrm{mg} / \mathrm{ml}$ for several cancer cell lines [23].

Therefore, the concentration ranges of C. monspeliensis extract displaying cytotoxicity against A-375 might be significant to support further studies since hexane extract of $C$. monspeliensis is enriched in vitamin $\mathrm{E}$ (11.5\%) which possesses well known antioxidant activity. Vitamin E acts as a peroxyl radical scavenger, preventing the propagation of free radicals in tissues, by reacting with them to form a tocopheryl radical which will then be oxidized by a hydrogen donor (such as Vitamin C) and thus return to its reduced state [24]. As it is fat soluble, it is incorporated into cell membranes and protects them from oxidative damage. The cancer preventive properties of vitamin E were firstly suspected when some studies showed that people in the Mediterranean area who consume diets enriched in vitamin E displayed a lower risk of colon cancer than people in Northern Europe and the U.S. [25,26]. More recently, the Melbourne Colorectal Cancer Study showed that dietary vitamins $\mathrm{E}$ and $\mathrm{C}$ were protective for both colon and rectal cancer, and that for both vitamins there was a dose-response effect of increasing protection [27]. Another clinical study supported a preventive effect of vitamin $\mathrm{E}$ in the development of prostate cancer. This study included over 29,000 elderly male smokers and showed that those taking vitamin $\mathrm{E}$ for six years had $32 \%$ fewer diagnoses of prostate cancer and $41 \%$ fewer prostate cancer deaths than men who did not take vitamin E [28]. More recently it has been demonstrated that Vitamin E also protects lipids and prevents the oxidation of polyunsaturated fatty acids [29].

Experimental studies also suggested detrimental effects of omega- 6 polyunsaturated fatty acids (PUFA), and beneficial effects of omega-3 PUFAs on mammary carcinogenesis, possibly due to the interaction with antioxidants. Significant interactions were also found between omega- 6 and long-chain omega- 3 PUFAs, with breast cancer risk inversely related to long-chain omega-3 PUFAs [30]. In this light, it is interesting to note that the hexane extract of $C$. monspeliensis was represented by fatty acids (43.3\%) among which the most abundant was the polyunsaturated fatty acid $(Z, Z, Z)-9,12-15$-octadecatrienoic acid (14.7\%) or linolenic acid.

In this sense, $C$. monspeliensis extract could be capable to exert its antiproliferative activity by the presence of the large amounts of fatty acids and vitamin $E$, in the light of the available literature that reports that dietary antioxidant polyphenols are capable to inhibit reactive oxygen species or free radicals [21] and/or to modulate uncontrolled proliferation [22-24].

\section{Experimental}

\section{Plant material}

Leaves of C. libanotis, C. monspeliensis and C. villosus were collected on March 2012 from plants growing in the National Park of Boukornine (Tunisie).

\section{Extraction}

The plant material was dried under shade and gross powdered prior to extraction. The powdered leaf $(30 \mathrm{~g})$ was extracted three times with $300 \mathrm{~mL}$ of hexane for 3 days, than the extracts were filtered through a filter paper, after that the extracts were concentrated by rotatory evaporation, and kept at $4^{\circ} \mathrm{C}$ until use.

\section{Gas chromatography}

Analytical gas chromatography was carried out on a Perkin-Elmer Sigma 115 gas chromatograph fitted with a HP-5 MS capillary column $(30 \mathrm{~m} \times 0.25 \mathrm{~mm}$ i.d.; 0.25 $\mu \mathrm{m}$ film thickness). Column temperature was initially kept at $45^{\circ} \mathrm{C}$ for $8 \mathrm{~min}$, then gradually increased to $280^{\circ} \mathrm{C}$ at $2.5^{\circ} \mathrm{C} \mathrm{min}^{-1}$, held for $15 \mathrm{~min}$ and finally raised to $295^{\circ} \mathrm{C}$ at $10^{\circ} \mathrm{C} \mathrm{min}{ }^{-1}$. Diluted samples $(1 / 100 \mathrm{v} / \mathrm{v}$, in $n$ pentane) of $1 \mu \mathrm{L}$ were injected manually at $250^{\circ} \mathrm{C}$, and in the splitless mode with a 1 minute purge-off due to the small amount of oil partially utilized for biological tests. Flame ionization detection (FID) was performed at $280^{\circ} \mathrm{C}$. Helium was the carrier gas $\left(1 \mathrm{~mL} \mathrm{~min}^{-1}\right)$. 


\section{Gas chromatography - mass spectrometry}

GC-MS analysis was performed on an Agilent 6850 Ser. II apparatus, fitted with a fused silica HP-1 capillary column $(30 \mathrm{~m} \times 0.25 \mathrm{~mm}$ i.d.; $0.33 \mu \mathrm{m}$ film thickness), coupled to an Agilent Mass Selective Detector MSD 5973; ionization energy voltage $70 \mathrm{eV}$; electron multiplier voltage energy $2000 \mathrm{~V}$. Mass spectra were scanned in the range 35-450 amu, scan time 5 scans/s. Gas chromatographic conditions were as reported above; transfer line temperature, $295^{\circ} \mathrm{C}$.

\section{Identification of components}

Most constituents were identified by gas chromatography by comparison of their retention indices (LRI) with either those of the literature [31,32] or with those of authentic compounds available in our laboratories. The retention indices were determined by GC-FID mode in relation to a homologous series of $n$-alkanes $\left(\mathrm{C}_{8}-\mathrm{C}_{28}\right)$ under the same operating conditions. Further identification was made by comparison of their mass spectra on both columns with either those stored in NIST 02 and Wiley 275 libraries or with mass spectra from the literature [32,33] and our home made library. Component relative concentrations were calculated based on GCFID peak areas without using correction factors.

\section{Cell lines}

J774.A1 murine monocyte/macrophage, A-375 human melanoma cell line and MCF-7 human breast cancer cell line were purchased from ATCC and used to evaluate the antiproliferative activity of the hexane extracts of Cistus spp. All the media and sera were purchased from HyClone (Euroclone, Paignton, Devon, UK); MTT [3 (4, 5-dimethylthiazol-2-yl)-2,5-phenyl-2H-tetrazolium bromide] and 6-mercaptopurine (6-MP) were from Sigma Chemicals (Milan, Italy). Cell culture was maintained at $37^{\circ} \mathrm{C}$ in a Hera Cell humidified $\mathrm{CO}_{2}$ incubator (Kandro Laboratory, Germany) with $5 \% \mathrm{CO}_{2}$.

\section{MTT antiproliferative assay}

Cells (J774.Al, A-375, and MCF-7 ) were harvested and suspended in complete culture media. Approximately $100 \mu \mathrm{l}$ of the cell suspension with a concentration of $2.0 \times 10^{4}, 3.0 \times 10^{3}, 5.0 \times 10^{3}$ cells, respectively were plated on 96-well microtiter plates and allowed to adhere at $37^{\circ} \mathrm{C}$ in $5 \% \mathrm{CO}_{2}$ and $95 \%$ air for $24 \mathrm{~h}$. Thereafter, the medium was replaced with $90 \mu \mathrm{L}$ of fresh medium, and a $10 \mu \mathrm{L}$ aliquot of serial dilution of each extract to test was added and the cells were incubated for tested time. Incubation was carried out for $72 \mathrm{~h}$ in the dark and at the end of the period, $20 \mu \mathrm{l}$ of MTT at a concentration of $5 \mathrm{mg} / \mathrm{ml}$ was added to each well. After 3 hours of incubation, culture media in each well was aspirated and $100 \mu \mathrm{l}$ of DMSO was added to dissolve the formazan products formed prior to recording the optical density (O.D.) at $570 \mathrm{~nm}$ with respect to the reference wavelength at $620 \mathrm{~nm}$. In some experiments, serial dilutions of 6-MP, as reference drug, were added. The cell viability was assessed through an MTT conversion assay (Bianco et al., 2012). The optical density (OD) of each well was measured with a microplate spectrophotometer (Titertek Multiskan MCC/340) equipped with a $620 \mathrm{~nm}$ filter. The test concentration which inhibits $50 \%$ of the cell population $\left(\mathrm{IC}_{50}\right)$ was obtained by Probit Analysis (SPSS Version 12.0.1, Chicago, IL, USA). All the experiments were carried out in triplicates and two independent experiments were performed for each test sample. The viability of each cell line in response to treatment with Cistus extracts was calculated as \% dead cells: 100 - (OD treated/OD control) $\times 100$.

\section{Conclusion}

The chemical composition of the hexane extracts from the three Cistus species can be useful in the chemosystematics of this complex genus. The antiproliferative activity of the Cistaceae hexane extracts observed for the first time in this study against human melanoma cell line A-375 deserve further investigations in order to determine the compounds, or their combinations, which are the main responsible for antiproliferative activity and its potential mechanism.

\section{Findings and description of additional material}

Plant material and extracts of the plants are available (MB). The GC-MS data are also available (FS).

\section{Competing interests}

The authors declare that they have no competing interests.

\section{Authors' contributions}

MBJ Collected and identified the plant material, prepared the extracts and drafted the manuscript. MEK Collected and identified the plant material and drafted the manuscript. FS performed the GC-MS analysis, identified the components and drafted the manuscript. GA performed the MTT antiproliferative assay and drafted the manuscript. SM performed the MTT antiproliferative assay and drafted the manuscript. VDF identified the components and drafted the manuscript. MB prepared the extracts, identified the components and drafted the manuscript. All authors read and approved the final manuscript.

\section{Acknowledgments}

This research was supported by Italian Government fund MIUR PRIN 2009 "Composti naturali da piante mediterranee e loro derivati sintetici con attivita' antitumorale". The GC-MS spectra were performed at the "C.S.I.A.S." of the University "Federico II" of Napoli. The assistance of the staff is gratefully appreciated.

\section{Author details}

'Laboratoire des Plantes Extremophiles - Biotechnologic Center Borj-Cedria Technopark, B.P. 9012050, Hammam-Lif, Tunisie. ²Department of Pharmacy, University of Naples "Federico II", Via D. Montesano, 49-80131, Naples, Italy. ${ }^{3}$ Department of Pharmacy, University of Salerno, via Ponte Don Melillo, 84084, Fisciano (Salerno), Italy. ${ }^{4}$ Department STEMBIO, Sect. of Organic Chemistry, University of Palermo, Viale delle Scienze, Parco d'Orleans II, 90128, Palermo, Italy. 
Received: 4 November 2012 Accepted: 4 February 2013

Published: 5 March 2013

\section{References}

1. Ferrandis P, Herrantz JM, Martínez-Sánchez JJ: Effect of fire on hardcoated Cistaceae seed banks and its influence on techniques for quantifying seed banks. Plant Ecol 1999, 144:103-114.

2. Guzmán B, Vargas P: Systematics, character evolution, and biogeography of Cistus L. (Cistaceae) based on ITS, trnL-trnF, and matK sequences. Mol Phylogenet Evol 2005, 37:644-660

3. Andrade D, Gil C, Breitenfeld L, Domingues F, Duarte AP: Bioactive extracts from Cistus ladanifer and Arbutus unedo L. Ind Crop Prod 2009, 30:165-167.

4. De Andres Al, Gomez-Serranillos MP, Iglesias I, Villar AM: Effects of extract of Cistus populifolius L. on the central nervous system. Phytother Res 1999, 13:575-579.

5. Küpeli E, Yesilada E: Flavonoids with anti-inflammatory and antinociceptive activity from Cistus laurifolius L. leaves through bioassayguided procedures. J Ethnopharmacol 2007, 112:524-530.

6. Barrajon-Catalan E, Fernandez-Arroyo S, Guillén E, Segura-Carretero A, Fernandez-Gutierrez A, Micol V: Cistaceae aqueous extracts containing ellagitannins show antioxidant and antimicrobial capacity, and cytotoxic activity against human cancer cells. Food Chem Toxicol 2010, 48:2273-2282.

7. Angelopoulou D, Costas Demetzos L, Dimas C, Perdetzoglou1 D, Loukis A: Essential oils and hexane extracts from Leaves and fruits of Cistus monspeliensis. Cytotoxic activity of ent-13-epi-Manoyl Oxide and its isomers. Planta Med 2001, 67:168-171.

8. Pomponio R, Gotti R, Santagati NA, Cavrini V: Analysis of catechins in extracts of Cistus species by microemulsion electrokinetic chromatography. J Chromatogr A 2003, 990:215-223.

9. Barrajon-Catalan E, Fernandez-Arroyo S, Roldan C, Guillen E, Saura D, Segura-Carretero A, Micol V: A systematic study of the polyphenolic composition of aqueous extracts deriving from several Cistus Genus species. Evolutionary Relationship. Phytochem Anal 2011, 22:303-312.

10. Chinou I, Demetzos C, Harvala C, Roussakis C, Verbist JF: Cytotoxic and antibacterial labdane-type diterpenes from the aerial parts of Cistus incanus subsp. creticus. Planta Med 1994, 60:34-36.

11. Kreimeyer J, Petereit F, Nahrstedt A: Separations of flavan-3-ols and dimeric proanthocyanidins by capillary electrophoresis. Planta Med 1998, 64:63-67.

12. Santagati NA, Salerno L, Attaguile G, Savoca F, Ronsisvalle G: Simultaneous determination of catechins, rutin, and gallic acid in cistus species extracts by HPLC with diode array detection. J Chromatogr Sci 2008, 46:150-156.

13. Qa'dan F, Petereit F, Nahrstedt A: Prodelphinidin trimers and characterization of a proanthocyanidin oligomer from Cistus albidus. Pharmazie 2003, 58:416-419.

14. Adamczyk B, Kitunen V, Smolander A: Protein precipitation by tannins in soil organic horizon and vegetation in relation to tree species. Biol Fert Soils 2008, 45:55-64.

15. Chaves N, Escudero JC, Gutierrez-Merino C: Quantitative variation of flavonoids among individuals of a Cistus ladanifer population. Biochem Syst Ecol 1997, 25:429-435.

16. Chaves N, Sosa T, Escudero JC: Plant growth inhibiting flavonoids in exudate of Cistus ladanifer and in associated soils. J Chem Ecol 2001, 27:623-631.

17. Bianco G, Russo R, Marzocco S, Velotto S, Autore G, Severino L: Modulation of macrophage activity by aflatoxins $B 1$ and B2 and their metabolites aflatoxins M1 and M2. Toxicon 2012, 59:644-50.

18. Kaefer CM, Milner JA: The role of herbs and spices in cancer prevention. J Nutr Biochem 2008, 19:347-361.

19. Perchellet JP, Gali HU, Perchellet EM, Klish DS, Armbrust AD: Antitumorpromoting activities of tannic acid, ellagic acid, and several gallic acid derivatives in mouse skin. Basic Life Sci 1992, 59:783-801.

20. Shoemaker M, Hamilton B, Dairkee SH, Cohen I, Campbell MJ: In vitro anticancer activity of twelve Chinese medicinal herbs. Phytother Res 2005, 19:649-651.

21. Halliwell B: Antioxidants in human health and disease. Ann Rev Nut 1996, $16: 33-50$.

22. Menendez JA, Vazquez-Martin A, Colomer R, Brunet J, Carrasco-Pancorbo A, Garcia-Villalba R, Fernandez-Gutierrez A, Segura-Carretero A: Olive oil's bitter principle reverses acquired autoresistance to trastuzumab (Herceptin) in HER2-overexpressing breast cancer cells. BMC Cancer 2007, 7:80

23. Friedman M, Mackey BE, Kim HJ, Lee IS, Lee KR, Lee SU, Kozukue E, Kozukue $\mathrm{N}$ : Structure-activity relationships of tea compounds against human cancer cells. J Agric Food Chem 2007, 55:243-253.

24. Traber Maret G, Stevens JF: Vitamins $C$ and E: beneficial effects from a mechanistic perspective. Free Radic Biol Med 2001, 51:1000-1013.

25. Berrino F, Muti P: Mediterranean diet and cancer. Eur J Clin Nutr 1989, 43(Suppl 2):49-55.

26. Khlat M: Cancer in Mediterranean migrants-based on studies in France and Australia. Cancer Causes Contr 1995, 6:525-31.

27. Kune $\mathrm{G}$, Watson $\mathrm{L}$ : Colorectal cancer protective effects and the dietary micronutrients folate, methionine, vitamins B6, B12, C, E, selenium, and lycopene. Nutr Cancer 2006, 56:11-21.

28. Heinonen OP, Albanes D, Virtamo J, Taylor PR, Huttenen JK, Hartman AM: Prostate cancer and supplementation with a- tocopherol and $\beta$ carotene: incidence and mortality in a controlled trial. J Natl Cancer Inst 1998, 90:440-446.

29. Ellie W, Rady Rolfes S: Understanding Nutrition. In. 12th editionEdited by Wadsworth WP. California: Cengage Learning; 2011

30. Thiébaut AC, Chajès V, Gerber M, Boutron-Ruault MC, Joulin V, Lenoir G, Berrino F, Riboli E, Bénichou J, Clavel-Chapelon F: Dietary intakes of omega- 6 and omega-3 polyunsaturated fatty acids and the risk of breast cancer. Int J Cancer 2009, 124:924-931.

31. Davies NW: Gas chromatographic retention indexes of monoterpenes and sesquiterpenes on methyl silicone and Carbowax 20M phases. J Chromatogr A 1990, 503:1-24.

32. Jennings W, Shibamoto T: Qualitative Analysis of Flavour and Fragrance volatiles by Glass Capillary Gas Chromatography. New York: Academic Press; 1980.

33. Adams RP: Identification of Essential Oil Components by Gas Chromatography/ Mass Spectroscopy. 4th edition. Carol Stream, Illinois: Allured Publishing Co; 2007.

doi:10.1186/1752-153X-7-47

Cite this article as: Ben Jemia et al:: Antiproliferative activity of hexane extract from Tunisian Cistus libanotis, Cistus monspeliensis and Cistus villosus. Chemistry Central Journal 2013 7:47.

Publish with ChemistryCentral and every
scientist can read your work free of charge
"Open access provides opportunities to our
colleagues in other parts of the globe, by allowing
anyone to view the content free of charge."
W. Jeffery Hurst, The Hershey Company.
- available free of charge to the entire scientific community
- cited in PubMed and archived on PubMed Central
- yours - you keep the copyright
Submit your manuscript here:
http://www.chemistrycentral.com/manuscript/

